\title{
PENGEMBANGAN PERANGKAT PEMBELAJARAN FISIKA BERBASIS PENDEKATAN ILMIAH YANG DIINTEGRASIKAN DENGAN PROSEDUR MATEMATIS UNTUK MENINGKATKAN HASIL BELAJAR SISWA PADA MATERI KALOR TINGKAT SMA
}

\author{
Jansensius Dani Hurint ${ }^{1)}$, Wasis $^{2)}$, Rudiana Agustini ${ }^{3)}$ \\ 1) Mahasiswa Program Studi Pendidikan Sains, Program Pascasarjana Universitas Negeri Surabaya \\ ${ }^{2), 3)}$ Dosen Pascasarjana Prodi Pendidikan Sains Univesrtitas Negeri Surabaya \\ E-mail:dani09hurint@yahoo.com
}

\begin{abstract}
This study aims to produce of learning materials which is effective to improve students' achievement. This learning is done by learning materials applying based on scientific approach integrated with mathematical procedure. This study is learning materials developing used 4D model and implemented by one group pretest-posttest design. Data analysis using descriptive qualitative. Results of the study as follow: validator evaluation for Plan of Conducting Teaching (Rencana Pelaksanaan Pelajaran (RPP)), student book, Student's Working Sheet (Lembar Kerja Siswa (LKS)) by category of appropriate to use. Test of students' cognitive, psychomotor, and affective study by categories of valid and easy to understand. Conducting RPP on 1st, 2nd, and 3rd meetings as much as $100 \%$. Students' cognitive competence achievement by pretest and posttest gain score as much as $25 \%$ for its high category, $75 \%$ for its medium category, and $0 \%$ for its low category. Finishing cognitive competence, psychomotor, and affective study results are $75 \%, 98.3 \%$ and $98.3 \%$ in that order. This study concluded that physics learning materials based on scientific approach which integrated with mathematical procedure is effective in improving students' achievement on heat subject matter for high school.
\end{abstract}

Keywords: Scientific Approach, Mathematical Procedure, Students' Achievement, Heat Subject Matter

Abstrak: Penelitian ini bertujuan untuk menghasilkan perangkat pembelajaran, yang efektif untuk meningkatkan hasil belajar siswa. Pembelajaran ini dilakukan dengan cara menerapkan perangkat pembelajaran berbasis pendekatan ilmiah yang diintegrasikan dengan prosedur matematis. Penelitian ini merupakan penelitian pengembangan dengan model 4D dan desain ujicoba one group pretest-posttest design. Teknik analisis data menggunakan deskriptif kualitatif. Hasil penelitian yang diperoleh sebagai berikut: hasil penilaian validator terhadap Rencana Pelaksanaan Pembelajaran (RPP), Buku Siswa, Lembar Kerja Siswa (LKS) dengan kategori sangat layak untuk digunakan. Tes hasil belajar kompetensi pengetahuan, keterampilan, dan sikap dengan kategori valid dan mudah dipahami. Keterlaksanaan RPP pada pertemuan I, II, dan III sebesar 100\%. Hasil belajar kompetensi pengetahuan dengan gain score pretest dan posttest sebesar 25\% untuk kategori tinggi, $75 \%$ untuk kategori sedang, dan $0 \%$ untuk kategori rendah. Ketuntasan hasil belajar pengetahuan, keterampilan, dan sikap secara berurutan adalah 75\%, 98,3\%, dan 98,3\%. Hasil penelitian menyimpulkan bahwa perangkat pembelajaran Fisika berbasis pendekatan ilmiah yang diintegrasikan dengan prosedur matematis efektif untuk meningkatkan hasil belajar siswa pada materi kalor tingkat SMA.

Kata kunci: Pendekatan Ilmiah, Prosedur Matematis, Hasil Belajar Siswa, Kalor

\section{PENDAhuluan}

Pelajaran Fisika merupakan pelajaran yang sulit dimengerti dikarenakan oleh rumus-rumus yang banyak dan juga diperlukan gambar-gambar yang sesuai dengan materi yang diajarkan. Rumus yang banyak dan kemampuan matematis yang kurang, sering menjadi salah satu kendala siswa dalam memahami konsep Fisika. Hal ini sesuai dengan pendapat Sugiharti dalam Mirawati, dan Masjkur (2013), siswa yang memiliki kemampuan matematis yang lemah secara otomatis akan mengalami kesulitan dalam memahami Fisika karena sebagian besar penyelesaian soal-soal Fisika dilakukan melalui pendekatan secara matematis.

Kemampuan matematis yang kurang, penyajian pembelajaran di kelas oleh guru yang masih cenderung konvensional juga turut berpengaruh terhadap rendahnya partisipasi siswa dalam pembelajaran. Siswa kurang berani bertanya kepada guru, kurang berani dalam menyampaikan pendapat, dan kurangnya kemampuan dalam memecahkan masalah. Hal-hal di atas sebenarnya menunjukkan gejala 
kesulitan belajar pada siswa sesuai dengan pendapat Maas dalam Mirawati, dan Masjkur (2013), kesulitan belajar merupakan suatu gejala yang dapat dilihat dalam berbagai jenis ciri tingkah laku siswa diantaranya: 1) menunjukkan hasil belajar yang rendah; 2) hasil yang dicapai tidak seimbang dengan usaha yang dilakukan; 3) lambat dalam melakukan tugas-tugas kegiatan belajar; dan 4) menunjukkan sikap yang kurang wajar, seperti acuh tak acuh.

Penelitian yang menunjukkan kaitan antara Fisika dan Matematika, antara lain oleh Bassok, dan Holyoak dalam Kereh, dkk (2013) yang menyarankan bahwa pembelajaran Matematika dan Fisika harusnya diajarkan secara terintegrasi agar kemampuan matematis dapat mendukung pemahaman konsep Fisika siswa.

Menurut Checkland (1993), berdasarkan sejarah perkembangan ilmu, didapatkan tiga karakteristik utama dari pendekatan ilmiah, yaitu:

\section{A. Reductionism}

Reductionism adalah pendekatan yang mereduksi kompleksitas permasalahan menjadi bagian-bagian yang lebih kecil, sehingga dapat dengan mudah diamati dan diteliti.

\section{B. Repeatability}

Repeatability adalah suatu pengetahuan yang dapat dicek kebenarannya dengan mengulang eksperimen atau penelitian yang dilakukan oleh orang lain di tempat dan waktu yang berbeda.

\section{Refutation}

Refutation adalah suatu ilmu yang harus memuat informasi yang dapat ditolak kebenarannya oleh orang lain.

Kemendikbud dalam Lazim (2013) memberikan konsepsi tersendiri bahwa pendekatan ilmiah dalam pembelajaran didalamnya mencakup komponen: mengamati, menanya, menalar, mencoba atau mencipta, menyajikan atau meng-komunikasikan.

1. Mengamati

Permendikbud Nomor 81a menyampaikan bahwa guru hendaklah membuka kesempatan secara luas dan bervariasi kepada peserta didik untuk melakukan pengamatan melalui kegiatan: melihat, menyimak, mendengar, dan membaca.

2. Menanya

Cook dalam Jacobsen, dkk (2009) mengemukakan bahwa: Ciri-ciri pertanyaan yang efektif adalah singkat, jelas, fokus, relevan, konstruktif, netral, dan terbuka. Jacobsen, dkk (2009) menambahkan bahwa: guru harus mempertimbangkan tujuan atau alasan mengajukan pertanyaan-pertanyaan tertentu. Pertanyaan tingkat rendah cocok untuk mengidentifikasi atau memperkuat informasi tertentu, sedangkan pertanyaan tingkat tinggi cocok untuk mendorong siswa berpikir tentang konten yang sedang dipelajari.

\section{Menalar}

Permendikbud Nomor 81a Tahun 2013, kegiatan mengasosiasi/mengolah informasi/menalar adalah memproses informasi yang sudah dikumpulkan baik terbatas dari hasil kegiatan eksperimen maupun hasil dari kegiatan mengamati dan kegiatan mengumpulkan informasi. Aktivitas menalar dalam konteks pembelajaran pada kurikulum 2013 dengan pendekatan ilmiah banyak merujuk pada teori belajar asosiasi atau pembelajaran asosiatif. Istilah asosiatif merujuk pada kemampuan mengelompokkan beragam ide dan mengasosiasikan beragam peristiwa untuk kemudian memasukkannya menjadi penggalan memori

4. Melakukan percobaan

Kegiatan pembelajaran dengan pendekatan eksperimen atau melakukan percobaan dilakukan melalui tiga tahap, yaitu: persiapan, pelaksanaan, dan tindak lanjut. Ketiga tahapan di atas, dijelaskan sebagai berikut:

\section{a. Persiapan}

- Menetapkan tujuan eksperimen

- Mempersiapkan alat atau bahan

- Mempersiapkan tempat eksperimen sesuai dengan jumlah peserta didik dan ketersediaan alat atau bahan

- Mempertimbangkan masalah keamanan dan kesehatan agar dapat memperkecil atau menghindari resiko yang mungkin timbul.

b. Pelaksanaan

- Selama proses eksperimen atau melakukan percobaan, guru ikut membimbing dan mengamati proses percobaan. Guru juga memberikan dorongan dan bantuan terhadap kesulitankesulitan yang dihadapi oleh peserta didik.

- Selama proses eksperimen atau melakukan percobaan, guru hendaknya memperhatikan situasi secara keseluruhan, termasuk membantu mengatasi dan memecahkan masalah-masalah yang akan menghambat kegiatan pembelajaran.

c. Tindak lanjut

- Peserta didik mengumpulkan laporan hasil eksperimen kepada guru

- Guru memeriksa hasil eksperimen peserta didik

- Guru memberikan umpan balik kepada peserta didik atas hasil eksperimen

- Guru dan peserta didik mendiskusikan masalahmasalah yang ditemukan selama eksperimen

- Guru dan peserta didik memeriksa dan menyimpan kembali segala bahan dan alat yang digunakan. 


\section{Mengkomunikasikan}

Dalam permendikbud Nomor 81a Tahun 2013, kegiatan mengkomunikasikan adalah menyampaikan hasil pengamatan, kesimpulan berdasarkan hasil analisis secara lisan, tertulis, atau media lainnya.

Menurut kamus besar bahasa Indonesia, prosedur didefinisikan sebagai metode langkah demi langkah secara pasti dalam memecahkan suatu masalah. Kilpatrick, dkk (2001) berpendapat: kelancaran prosedural (procedural fluency) mengacu pada pengetahuan tentang prosedur, pengetahuan tentang kapan dan bagaimana menggunakannya secara tepat, dan ketrampilan melakukan prosedur secara fleksibel, akurat, dan efisien. Dengan demikian, indikator untuk kelancaran prosedur ini antara lain adalah siswa mampu:
a. Menggunakan prosedur,
b. Memanfaatkan prosedur,
c. Memilih prosedur,
d. Memperkirakan hasil suatu prosedur,
e. Memodifikasi atau memperhalus prosedur, dan
f. Mengembangkan prosedur.

Matematika adalah ilmu tentang pola dan urutan. Melibatkan diri dalam ilmu tentang pola dan urutan dalam mengerjakan matematika diperlukan usaha dan waktu. Ada banyak ide yang dapat dipelajari. Ide-ide ini sering muncul dalam daftar "keterampilan dasar", contohnya siswa harus dapat menghitung dengan benar, mengetahui fakta-fakta dasar untuk penjumlahan dan perkalian, mempunyai metode yang efisien untuk bilangan asli, pecahan, dan desimal, mengetahui faktafakta pengukuran seperti berapa inci dalam satu kaki, mengetahui nama-nama dalam bentuk geometri, dan sebagainya (Walle, 2008).

Sejalan dengan pendapat Walle (2008) di atas dan didukung oleh observasi awal peneliti terhadap kemampuan matematis siswa kelas X tingkat SMA yang masih kurang, kemampuan matematis terutama kemampuan dasar matematis sangat perlu menjadi perhatian guru Fisika dalam pembelajaran karena prosedur matematis dalam Fisika sering digunakan dalam penyelesaian masalah-masalah Fisika., siswa dapat memperoleh informasi tentang fakta dengan mempelajari prosedur matematis karena matematika itu terstruktur (sangat terorganisir, penuh dengan pola, dapat diprediksi) dan sebuah prosedur yang dikembangkan dengan hati-hati bisa menjadi alat yang ampuh untuk menyelesaikan tugas rutin.

Penelitian pengembangan perangkat pembelajaran ini mengintegrasikan prosedur matematis di dalam pembelajaran Fisika dengan menambahkan kemampuan dasar matematis pada buku siswa, khususnya dalam setiap penyelesaian contoh-contoh soal yang memerlukan kemampuan dasar matematis. Kemampuan dasar matematis yang diberikan pada buku siswa disesuaikan dengan materi ajar yang dipilih dalam penelitian ini yaitu konsep kalor. Soal-soal latihan Fisika dalam konsep kalor penelitian ini membutuhkan kemampuan dasar matematis seperti: simbolisasi dalam aljabar, suku-suku sejenis dan tak sejenis, operasi dalam ekspresi aljabar, persamaan aljabar, penyelesaian persamaan linear, grafik persamaan linear, operasi monomial dan polinomial, serta operasi bilangan desimal dan pangkat. Siswa dapat menyelesaikan soalsoal Fisika karena didukung oleh kemampuan dasar matematis dan pemahaman konsep kalor yang baik menjadi harapan dalam penelitian ini, terutama dalam meningkatkan hasil belajar siswa.

\section{METODE PENELITIAN}

Penelitian ini merupakan penelitian pengembangan yakni mengembangkan perangkat pembelajaran yang meliputi rencana pelaksanaan pembelajaran (RPP), lembar kegiatan siswa (LKS), dan buku siswa.

Prosedur pengembangan perangkat dalam penelitian ini menggunakan model pengembangan perangkat four $D$ atau model $4 D$. Model 4D ini terdiri dari empat tahap, yaitu tahap pendefinisian (define), perancangan (design), pengembangan (develop), dan penyebaran (disseminate), namun pada penelitian ini hanya sampai pada tahap pengembangan (develop), yaitu uji pengembangan kuantitatif.

\section{A. Tahap pendefinisian (define)}

Tujuan dari tahap ini adalah menetapkan dan mendefinisikan persyaratan-persyaratan atau kebutuhan-kebutuhan pembelajaran. Penetapan tahap ini dilakukan dengan cara menganalisis tujuan dalam batasan materi pelajaran. Langkah-langkah tahap pendefinisian meliputi analisis awal akhir, analisis siswa, analisis tugas, analisis konsep, dan perumusan tujuan pembelajaran.

\section{Analisis awal akhir}

Konsep adalah gambaran umum dari suatu ide atau gagasan berdasarkan sistem penalaran. Prinsip adalah ketentuan yang harus ada atau dijalankan. Konsep dan prinsip Fisika dalam penelitian ini lebih menjelaskan tentang berbagai peristiwa alam dan menyelesaikan masalah secara kualitatif maupun kuantitatif. Hal ini dapat dicapai dengan memberi kesempatan pada siswa untuk menggali potensi diri mereka sendiri melalui pembelajaran dengan pendekatan ilmiah. Salah satu pokok bahasan Fisika yang dapat didesain melalui pendekatan ilmiah adalah kalor dan perpindahan kalor. Pada bagian awal, siswa diminta untuk mengamati peristiwa tentang kalor dalam kehidupan sehari-hari dan melakukan studi pustaka hingga siswa menemukan permasalahan yang menstimulus pikiran siswa untuk menemukan pemecahannya secara ilmiah. 


\section{Analisis siswa}

Beberapa pertimbangan dasar dalam mengembangkan instrumen penelitian ini adalah:

a. Kompetensi Siswa

Siswa yang menjadi subyek dalam penelitian ini adalah siswa kelas $\mathrm{X}$ yang sedang berada pada masa transisi dari pendidikan tingkat SMP menuju SMA. Pendidikan pada tingkat SMA memiliki permasalahanpermasalahan yang lebih kompleks dan spesifik untuk diselesaikan secara ilmiah. Secara konten, siswa sudah mempelajari kalor dan perpindahan kalor ketika masih di SMP, sehingga konsep dasar tentang kalor telah diperoleh oleh siswa.

Pemahaman konsep kalor memerlukan prosedurprosedur matematis dalam menyelesaikan permasalahan dalam Fisika. Beberapa prosedur matematis telah diajarkan oleh guru Matematika di sekolah, namun berdasarkan pengalaman peneliti dalam mengajar mata pelajaran Fisika, siswa masih kesulitan tentang prosedur matematis yang digunakan dalam penyelesaian soalsoal Fisika.

\section{b. Sikap Siswa}

Pembelajaran Fisika melalui pendekatan ilmiah lebih mengedepankan keaktifan siswa dalam berfikir dan bertindak, sehingga siswa memiliki rasa keingintahuan yang tinggi. Pemberian prosedur matematis dalam buku siswa dapat membantu siswa dalam menyelesaikan soal-soal Fisika secara sistematis.

\section{c. Penggunaan Bahasa}

Secara umum, istilah-istilah dalam konsep kalor telah diajarkan kepada siswa ketika siswa masih berada di bangku SMP, sehingga beberapa istilah seperti kalor jenis, kapasitas kalor, asas Black, dan perpindahan kalor secara kebahasaan siswa tidak akan mengalami kesulitan.

\section{d. Alat Praktikum}

Alat praktikum yang digunakan dalam penelitian ini, seperti termometer, stopwatch, dan timbangan digital telah sering diketahui siswa dalam kehidupan sehari-hari, kecuali jangka sorong yang penggunaannya sangat jarang ditemukan dalam kehidupan sehari-hari. Alat praktikum yang telah diketahui penggunaannya oleh siswa, dapat membantu siswa dalam melakukan percobaan sederhana dalam kegiatan praktikum untuk menemukan faktor-faktor yang mempengaruhi kalor pada suatu benda, konsep Asas Black, dan bagaimana cara kalor berpindah.

\section{Analisis tugas}

Analisis tugas merupakan langkah awal dalam pengembangan pembelajaran. Berikut merupakan gambaran analisis tugas dari pengembangan perangkat pembelajaran Fisika berbasis pendekatan ilmiah yang diintegrasikan dengan prosedur matematis.

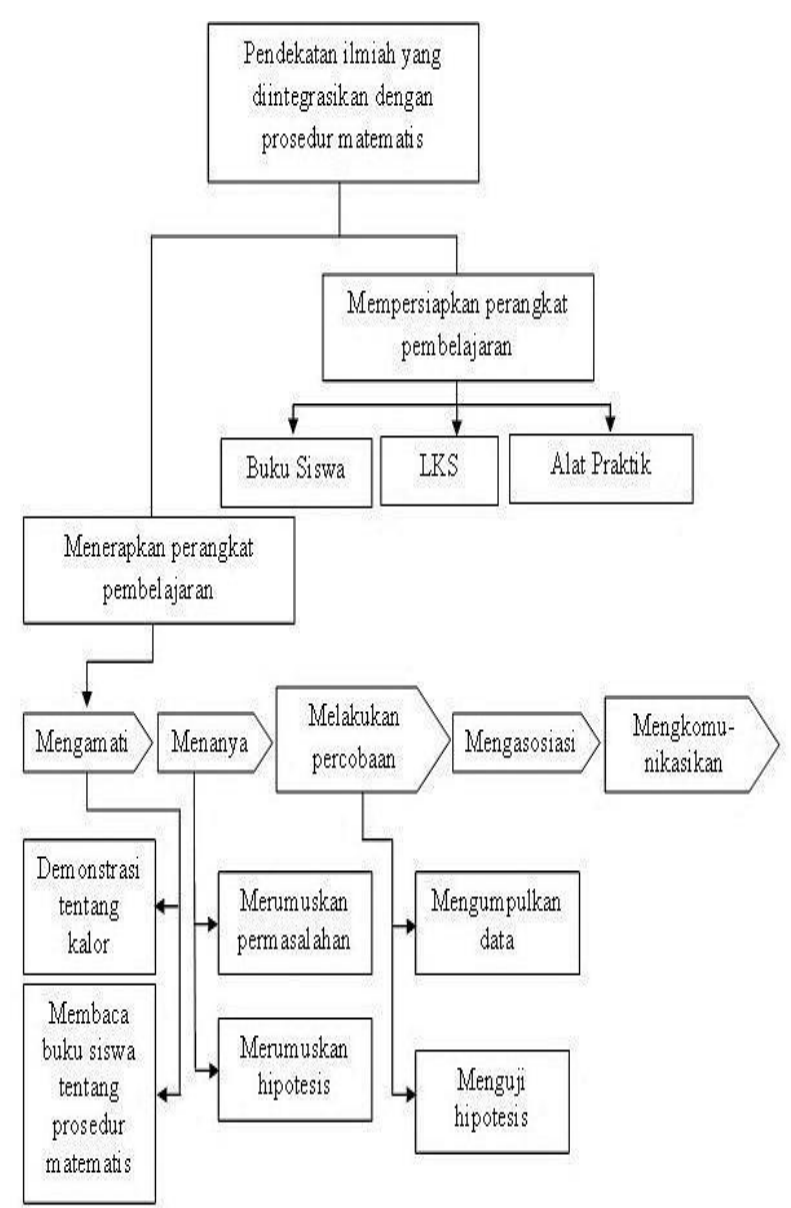

Gambar 1. Peta prosedur penelitian

Bagian awal kegiatan pembelajaran, siswa diberikan perangkat pembelajaran yang meliputi buku siswa, LKS, dan alat praktikum. Guru melakukan demonstrasi berupa pemutaran video tentang peristiwa pemanasan air hingga menjadi uap air, animasi Phet simulation tentang percampuran dua zat yang berbeda suhunya, dan perpindahan kalor secara konduksi dalam kehidupan sehari-hari. Demonstrasi ini diharapkan dapat mengantar siswa untuk mengingat kembali konsep kalor yang pernah didapatkan ketika masih di bangku SMP dan mengembangkannya ketika di SMA.

Guru menstimulun siswa kembali dengan meminta siswa untuk membaca buku siswa yang berisi materi dan konsep kalor serta prosedur matematis yang digunakan dalam penyelesaian soal-soal latihan dan melakukan studi pustaka dari referensi lain seperti buku pegangan siswa, dan internet.

Pada tugas pertama, siswa diminta untuk merumuskan permasalahan-permasalahan yang ditemukan setelah menyimak demonstrasi dan melakukan studi pustaka. Setelah merumuskan masalah, siswa diminta merumuskan hipotesis sebagai jawaban sementara dari permasalahan yang dihadapi. Peran guru sebagai fasilitator sangat diharapkan pada bagian ini, karena siswa belum terbiasa untuk merumuskan hipotesis yang merupakan bagian dalam pembelajaran 
dengan pendekatan ilmiah dan merupakan roh dalam kurikulum 2013.

Tugas kedua adalah siswa melakukan percobaan untuk menguji hipotesis yang telah dirumuskan pada tugas pertama. LKS yang telah disusun dan dibagikan kepada siswa dijadikan penuntun bagi siswa dalam melakukan percobaan agar hasil percobaan dapat mengarah pada penerimaan atau penolakan terhadap rumusan hipotesis siswa.

Tugas ketiga adalah mengasosiasi dan mengkomunikasikan. Pada tugas mengasosiasi dan mengkomunikasikan ini, siswa berdiskusi dalam kelompok tentang hasil percobaan yang diperoleh dan mengungkapkan prosedur matematis yang masih belum dipahami oleh anggota kelompok. Peran guru sebagai fasilitator sangat diperlukan pada tugas ini, agar diskusi yang dilakukan oleh masing-masing kelompok dapat mengarah pada penyelesaian terhadap permasalahan siswa pada tugas pertama di atas.

\section{Analisis konsep}

Konsep dan hukum Fisika yang digunakan dalam pembelajaran ini, digambarkan sebagai berikut:

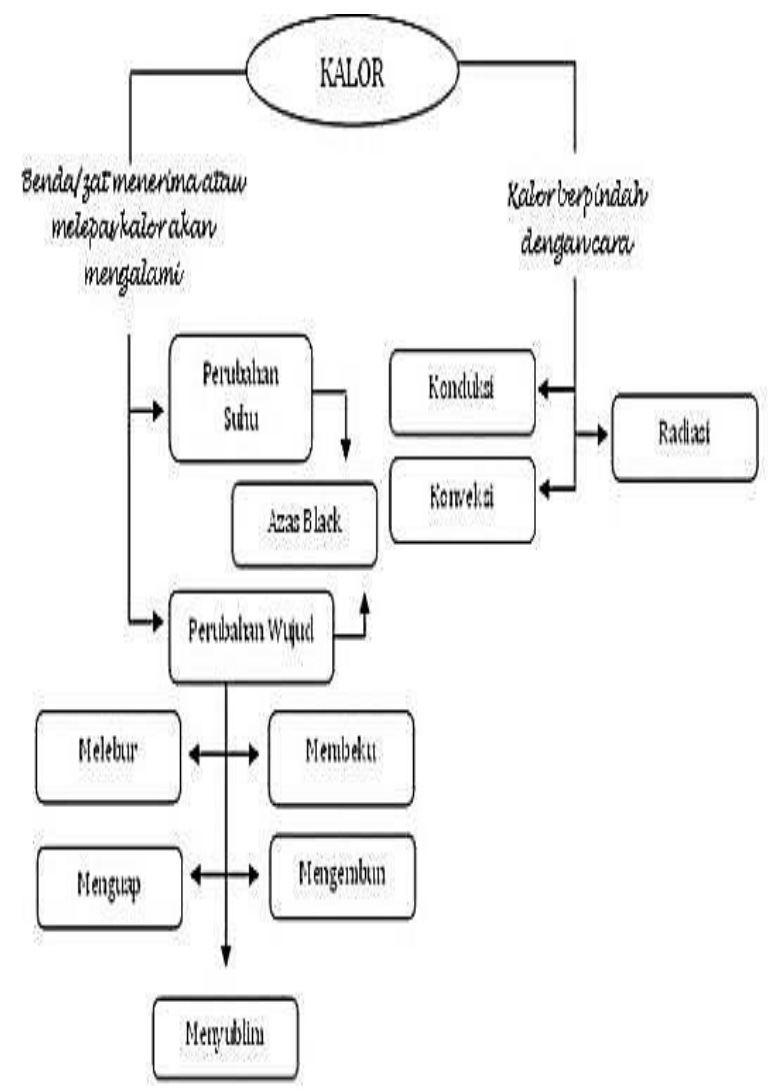

Gambar 2. Peta Materi Ajar

\section{B. Tahap perancangan (design)}

Pada tahap ini dihasilkan prototipe perangkat pembelajaran yang meliputi penyusunan tes, pemilihan media, dan penyusunan perangkat pembelajaran.
Prototipe perangkat pembelajaran dijabarkan sebagai berikut:

1. Penyusunan tes

Tes yang akan digunakan dalam ujicoba perangkat pembelajaran ini adalah tes hasil belajar. Tes hasil belajar ini mencakup tiga ranah, yaitu ranah pengetahuan berupa pre-test dan posttest, ranah keterampilan, dan ranah sikap.

2. Pemilihan media

Media yang digunakan dalam pembelajaran meliputi satu set alat praktikum kalor, power point dan internet yang akan menampilkan berbagai fakta penerapan Fisika dalam kehidupan sehari-hari, buku siswa, dan LKS.

3. Penyusunan perangkat pembelajaran

Perangkat pembelajaran dalam penelitian ini meliputi silabus, rencana pelaksanaan pembelajaran (RPP), buku siswa, lembar kerja siswa (LKS), dan lembar penilaian (LP). Perangkat pembelajaran disusun dan mengacu pada analisis siswa serta tujuan pembelajaran yang telah dianalisis di bagian awal. Penyusunan dan pengembangan perangkat pembelajaran yang disusun adalah perangkat pembelajaran berbasis pendekatan ilmiah yang diintegrasikan dengan prosedur matematis untuk meningkatkan hasil belajar siswa.

\section{Tahap pengembangan (develop)}

Uji pengembangan kuantitatif ini dilaksanakan pada kelas X IPA 1 di SMA Katolik W.R. Soepratman 020 Samarinda dengan menggunakan desain one group pretest-posttest design (Prabowo, 2011).

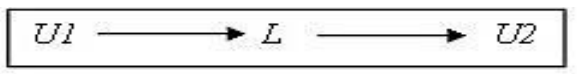

Teknik pengumpulan data dalam penelitian ini adalah:

1. Validasi

Perangkat pembelajaran (RPP, LKS, dan buku siswa) ditelaah oleh validator untuk memberikan penilaian terhadap kelayakan penggunaan RPP, LKS, dan buku siswa.

2. Observasi

Observasi dalam penelitian ini meliputi keterlaksanaan pembelajaran, aktivitas siswa selama pembelajaran, penilaian hasil belajar ranah keterampilan dan sikap siswa, serta kendala yang dialami siswa selama mengikuti pembelajaran Fisika berbasis pendekatan ilmiah yang diintegrasikan dengan prosedur matematis. Observasi keterlaksanaan pembelajaran, aktivitas siswa, penilaian ranah keterampilan dan sikap, serta kendala selama proses pembelajaran dilakukan selama kegiatan pembelajaran berlangsung. 


\section{Angket}

Metode angket digunakan untuk mengukur respon siswa. Angket respon siswa diberikan kepada siswa setelah mengikuti proses pembelajaran dan postest.

4. Metode Tes

Pemberian tes dilakukan dua kali, yaitu sebelum diberi perlakuan (pretest) dan setelah diberi perlakuan (posttest). Waktu tes dilakukan di luar jam pelajaran yang dialokasikan untuk penelitian. Penilaian tes didasarkan pada pedoman penskoran yang telah dikembangkan oleh peneliti. Tes digunakan untuk mengetahui hasil belajar Fisika.

\section{Instrumen dalam penelitian ini meliputi:}

\section{Lembar Validasi}

Lembar validasi digunakan untuk mengukur kelayakan perangkat pembelajaran yang meliputi lembar validasi rencana pelaksanaan pembelajaran (RPP), lembar validasi lembar kegiatan siswa (LKS), dan lembar validasi buku siswa.

2. Lembar Pengamatan Keterlaksanaan Pembelajaran

Lembar pengamatan keterlaksanaan pembelajaran digunakan untuk mengetahui kesesuaian pelaksanaan pembelajaran dengan skenario yang telah disiapkan dalam bentuk RPP.

\section{Lembar Pengamatan Aktivitas Siswa}

Lembar pengamatan aktivitas siswa digunakan untuk mengamati aktivitas siswa selama kegiatan pembelajaran berlangsung yang diisi oleh dua orang pengamat. Tingkat reliabilitas data dua orang pengamat digunakan interobserver agreement dengan menggunakan analisis statistic percentage of agreement, yaitu:

$$
R=\left(1-\frac{A-B}{A+B}\right) \times 100 \%
$$

(Borich, 1994)

\section{Keterangan:}

$R=$ Reliabilitas (instrumen dianggap reliabel apabila $R \geq 0,75$ ).

$A=$ Frekuensi aspek keterampilan yang teramati oleh pengamat yang memberikan frekuensi tinggi.

$B=$ Frekuensi aspek keterampilan yang teramati oleh pengamat yang memberikan frekuensi rendah.

\section{Angket Respon Siswa Dalam Pembelajaran}

Angket respon siswa digunakan untuk mengukur pendapat dan tanggapan siswa terhadap kegiatan pembelajaran yang meliputi: materi/isi pelajaran, format buku siswa, LKS, suasana belajar, dan cara guru mengajar.
Hasil angket dinyatakan dalam persentase:

$$
P=\frac{\sum K}{\sum N} \times 100 \%
$$

Keterangan:

$$
\begin{aligned}
& P=\text { Persentase } \\
& \Sigma K=\text { Jumlah jawaban responden } \\
& \Sigma N=\text { Jumlah responden. }
\end{aligned}
$$

\section{Lembar Penilaian Hasil Belajar}

Lembar penilaian hasil belajar digunakan untuk mengukur peningkatan yang dicapai siswa setelah mengikuti pembelajaran. Perhitungan peningkatan yang dicapai menggunakan gain score. Penilaian hasil belajar dalam penelitian ini mengacu pula pada standar penilaian kurikulum 2013 yang mencakup kompetensi pengetahuan, keterampilan, dan sikap.

6. Lembar pengamatan kendala di lapangan

Lembar pengamatan kendala di lapangan digunakan untuk mencatat segala macam kendala atau hambatan yang terjadi selama proses pembelajaran yang diamati oleh dua orang pengamat. Lembar pengamatan ini berisikan jenis hambatan yang dianggap pengamat dapat menghambat kegiatan pembelajaran serta solusi yang diberikan pengamat untuk mengatasi hambatan yang terjadi.

Pengolahan data dalam penelitian ini dilakukan dengan menggunakan analisis deskriptif yang meliputi:

\section{Analisis Validitas Perangkat}

Perangkat pembelajaran (RPP, buku siswa, LKS, dan tes hasil belajar) ditelaah oleh validator untuk memberikan penilaian terhadap kelayakan penggunaannya. RPP, buku siswa, dan LKS ditelaah dengan instrumen 1 , instrumen 2 , dan instrumen 3 . Lembar penilaian tes hasil belajar yang dikembangkan, dilakukan validasi isi, bahasa dan penulisan soal sesuai dengan instrumen 4. Data hasil validasi dianalisis secara deskriptif kualitatif. Dalam penelitian ini passing grade (batas penerimaan) adalah skor rerata $(\bar{X})$ dari hasil penilaian para validator dan kemudian dicocokkan dengan kriteria penilaian perangkat hasil pembelajaran.

\begin{tabular}{|c|c|}
\hline Interfald skar" & 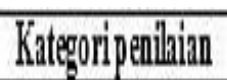 \\
\hline$=3,50$ & Sampatlaglik \\
\hline $3,00<\frac{d}{d}=3.49$ & Laydi \\
\hline $2,00<\frac{\mathrm{H}}{\mathrm{H}}=2,99$ & Sedang \\
\hline $1,00<H=1,99$ & Kuranly \\
\hline$=1,00$ & Rendarin \\
\hline
\end{tabular}
Kriteria penilaian perangkat hasil pembelajaran dapat disajikan pada Tabel 3.2 berikut:

Tabel 1. Kriteria Pengkategorian Penilaian RPP, buku siswa dan LKS 


\section{Analisis Keterlaksanaan Pembelajaran}

Analisis hasil penilaian yang diberikan oleh pengamat terhadap keterlaksanaan pembelajaran Fisika melalui pendekatan ilmiah yang diintegrasikan dengan prosedur matematis menggunakan ketentuan sebagai berikut:

$$
\begin{array}{ll}
0.0-1.00 & \text { Tidak baik } \\
1.10-2.00 & \text { Kurang baik } \\
2.10-3.00 & \text { Cukup baik } \\
3.10-4.00 & \text { Baik }
\end{array}
$$

(Budiningarti dalam Rusli, 2013)

\section{Analisis Data Aktivitas Siswa Selama Kegiatan} Pembelajaran.

Analisis data aktivitas siswa dilakukan dengan mengamati kelas setiap kali tatap muka. Data hasil pengamatan dianalisis dengan menggunakan persentase $(P)$ dan dianalisis dengan analisis deskriptif kuantitatif:

$$
P=\frac{\text { rata }- \text { rata dari dua pengamat }}{\text { jumlah pengamatan }} \times 100 \%
$$

4. Analisis Data Respon Siswa Terhadap Perangkat Pembelajaran dan Kegiatan Pembelajaran.

Data hasil respon yang diberikan siswa dianalisis dengan menggunakan statistic desktiptif kuantitatif dengan persentase. Persentase tiap respon dihitung dengan cara: jumlah aspek yang muncul dibagi dengan jumlah siswa dikalikan $100 \%$.

\section{Analisis Data Tes Hasil Belajar}

Analisis data tes hasil belajar dihitung dengan menggunakan gain score. Secara matematis, gain score dirumuskan sebagai berikut:

$$
\begin{aligned}
& \langle g\rangle \equiv \% \frac{\langle G\rangle}{\%\langle G\rangle_{\max }} \\
& \quad=\left(\%\left\langle S_{f}\right\rangle-\%\left\langle S_{i}\right\rangle\right) /\left(100-\%\left\langle S_{i}\right\rangle\right)
\end{aligned}
$$

Kategori gain score:

Tinggi, jika $\langle g\rangle>0,7$

Sedang, jika $0,7>\langle g\rangle>0,3$

Rendah, jika $\langle g\rangle<0,3$

(Hake, 1999)

Perhitungan nilai untuk mengetahui ketuntasan siswa pada ranah pengetahuan, keterampilan, dan sikap menggunakan rumus berikut:

$$
\text { Nilai }=\frac{\text { Skor yang diperoleh }}{\text { Skor maksimal }} \times 100
$$

(Kurniasih, dan Sani, 2014)
Tabel 2. Konversi nilai hasil belajar

\begin{tabular}{|c|c|c|c|}
\hline \multirow{2}{*}{ Predilast } & \multicolumn{3}{|c|}{ Nilaikompetensi } \\
\cline { 2 - 3 } & Pengetahuan & Keterampilan & Silkap \\
\hline A & 4 & 4 & \multirow{2}{*}{ Sangat baik } \\
\hline A- & 3,66 & 3,66 & \\
\hline B + & 3,33 & 3,33 & \multirow{2}{*}{ Baili } \\
\hline B & 3 & 3 & \\
\hline B- & 2,66 & 2,66 & \\
\hline C+ & 2,33 & 2,33 & \multirow{2}{*}{ Culup } \\
\hline C & 2 & 2 & \multirow{2}{*}{ Kurang } \\
\hline C- & 1,66 & 1,66 & \\
\hline D+ & 1,33 & 1,33 & \\
\hline D & 1 & 1 & \\
\hline
\end{tabular}

Perhitungan konversi nilai ke dalam bentuk pembobotan sebagai berikut:

$$
\text { Pembobotan nilai }=\frac{\text { Skor yang diperoleh }}{\text { Skor maksimal }} \times 4
$$

Permendikbud Nomor 66 Tahun 2013 menyatakan bahwa bobot nilai ketuntasan minimal untuk ranah pengetahuan dan keterampilan adalah 2,66 dengan predikat $\mathrm{B}$, dan nilai baik untuk ranah sikap.

\section{Analisis kendala selama kegiatan pembelajaran}

Temuan kendala-kendala selama pembelajaran dianalisis secara deskriptif naratif melalui diskusi antara pengamat dan peneliti. Hasil diskusi kemudian dicari solusi alternatifnya untuk mengatasi kendala yang muncul baik sebelum maupun selama proses pembelajaran.

\section{HASIL PENELITIAN DAN DISKUSI}

\section{A. Validitas Perangkat Pembelajaran}

Perangkat pembelajaran yang telah dikembangkan oleh peneliti meliputi Rencana Pelaksanaan Pembelajaran (RPP), buku siswa, Lembar Kerja Siswa (LKS), dan lembar penilaian. Perangkat ini dikembangkan dengan mengikuti langkah-langkah pendekatan ilmiah, dimana pembelajaran diawali dengan pemberian fakta berupa pemutaran video, simulasi program $p H E T$, dan demonstrasi oleh guru tentang peristiwa kalor dan perpindahannya dalam kehidupan sehari-hari. Fakta yang diberikan diharapkan dapat menjadi stimulus bagi siswa untuk menemukan permasalahan dan merumuskannya, serta menuliskan hipotesis sebagai jawaban sementara atas permasalahan yang ditemukan, kemudian siswa melakukan percobaan dan pengamatan untuk menguji kebenaran hipotesis yang telah dirumuskan. Proses belajar mengajar Fisika sangat memungkinkan siswa untuk terlibat aktif dalam pembelajaran (Gedgrave, 2009). 
Perangkat pembelajaran yang telah dikembangkan oleh peneliti, divalidasi oleh dua orang validator dan telah diujicobakan pada kelas terbatas dan uji pengembangan kuantitatif di kelas X IPA 1 SMA Katolik W.R. Soepratman 020 Samarinda.

\section{Rencana Pelaksanaan Pembelajaran (RPP)}

Rencana Pelaksanaan Pembelajaran (RPP) yang akan digunakan dalam proses kegiatan pembelajaran, terlebih dahulu divalidasi oleh validator. Proses validasi ini diharapkan dapat mengarahkan proses pembelajaran agar sesuai dengan tujuan pembelajaran. Saran dan masukan validator terhadap RPP adalah rumusan tujuan pembelajaran harus memenuhi ketentuan audiens, behavior, condition, dan degree, rumusan tujuan pembelajaran harus terpisah untuk dua kali pertemuan, dan setiap rumusan kompetensi dasar harus disertakan pula rumusan indikator ketercapaiannya.

\section{Buku Siswa}

Buku siswa yang disusun oleh peneliti, berbeda dengan buku ajar di sekolah. Perbedaan ini terletak pada penambahan prosedur matematis yang disesuaikan dengan materi yang diajarkan. Prosedur matematis yang diberikan diharapkan dapat mengatasi kesulitan siswa dalam menyelesaikan soal-soal latihan yang diberikan. Hal ini didasarkan pada pengalaman peneliti dalam mengajar Fisika, dimana hampir sebagian besar siswa kelas $\mathrm{X}$ masih memiliki kemampuan matematis yang lemah. Lemahnya kemampuan matematis siswa juga terlihat pada hasil pretest dalam penelitian ini. Sejalan dengan pengalaman peneliti, Sugiharti dalam Mirawati, dkk (2013) menemukan bahwa siswa yang memiliki kemampuan matematis yang lemah secara otomatis akan mengalami kesulitan dalam memahami Fisika. Perbedaan lain dalam buku siswa ini adalah adanya kunci jawaban dari setiap latihan soal yang diberikan dalam buku siswa. Kunci jawaban ini dapat digunakan oleh siswa sebagai pembanding terhadap hasil jawaban dari setiap soal latihan yang dikerjakan siswa.

Hasil validasi buku siswa dengan skor 3,89 untuk kelayakan isi, 3,80 untuk kebahasaan, dan 3,71 untuk penyajian materi dinyatakan valid dan telah diuji cobakan pada kelas terbatas serta dilanjutkan pada uji pengembangan kuantitatif . Beberapa saran atau revisi kecil dari validator diantaranya penulisan satuan perubahan suhu, penyertaan kutipan dari setiap tabel, proses perubahan es hingga menjadi uap air dinyatakan dalam bentuk grafik hubungan suhu $(T)$ dan kalor yang diserap atau diterima $(Q)$, dan penyertaan penomoran serta sumber kutipan dari gambar yang diberikan.

\section{Lembar Kerja Siswa (LKS)}

Lembar Kerja Siswa (LKS) yang dikembangkan mengacu pada pendekatan ilmiah yang berorientasi pada kegiatan yang berpusat pada siswa. LKS ini mencakup kegiatan mengamati, menanya, menalar, melakukan percobaan dan pengamatan, serta mengkomunikasikan. Kegiatan mengamati dimulai dengan pemberian fakta tentang video pemanasan air hingga menjadi uap air pada pertemuan I, simulasi program $p H E T$ tentang Asas Black pada pertemuan II, dan demonstrasi oleh guru tentang peristiwa perpindahan kalor pada pertemuan III.

Dari fakta ini, kemudian siswa merumuskan permasalahan dengan menuliskan pertanyaan yang berkaitan dengan kegiatan mengamati tersebut. Pertanyaan yang dibuat oleh siswa selanjutnya dirumuskan dalam sebuah hipotesis sebagai jawaban sementara atas pertanyaan siswa. Siswa melakukan percobaan, pengamatan, dan pencarian informasi dari sumber lain yang relevan sebagai bagian dari kegiatan menalar.

Hasil dari melakukan percobaan dan pencarian informasi, selanjutnya dikomunikasikan dalam diskusi kelompok untuk mendapatkan balikan dalam diskusi kelas. Penelitian tentang pendekatan ilmiah dalam bentuk kegiatan laboratorium menyimpulkan bahwa pendekatan laboratorium dalam pembelajaran Fisika dapat memberikan pencapaian kompetensi ilmiah siswa yang lebih baik (Putra, 2013).

Adapun rata-rata skor validasi LKS oleh dua orang validator yang meliputi: a) aspek petunjuk 4,17 ; b) kelayakan isi 4,21; dan c) prosedur 4,75. Hasil validasi tersebut dapat menyimpulkan bahwa LKS yang telah dikembangkan oleh peneliti layak untuk diimplementasikan pada uji coba kelas terbatas dan uji pengembangan kuantitatif dengan kategori sangat baik.

\section{B. Keterlaksanaan Tahapan Pembelajaran}

Alat observasi untuk mengetahui kemampuan guru dalam mengelola pembelajaran, diperlukan untuk mengetahui keterlaksanaan tahapan pembelajaran. Tahapan yang diamati dalam proses pembelajaran adalah: 1) Mengamati, yang meliputi: a) mengamati fenomena/demonstrasi yang dimunculkan guru; b) mencari informasi pada buku siswa; 2) Menanya, yang meliputi: a) merumuskan permasalahan; b) merumuskan hipotesis; 3) Melakukan percobaan dan pengamatan, yang meliputi: a) melakukan percobaan; b) mencatat hasil pengamatan; 4) Menalar; yang meliputi: a) berdiskusi dalam kelompok; b) menjawab pertanyaan LKS; 5) Mengkomunikasikan, yang meliputi: a) menyampaikan hasil diskusi; b) menanggapi hasil diskusi.

Hasil pengamatan keterlaksanaan tahapan pembelajaran disajikan berikut: 


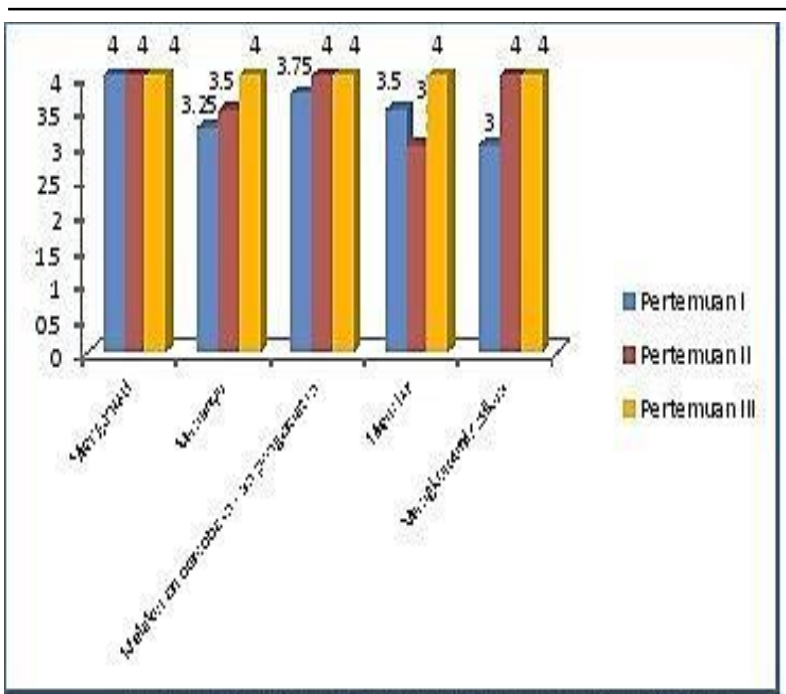

Gambar 3. Diagram Keterlaksanaan Pembelajaran

Hasil implementasi rencana pelaksanaan pembelajaran pada pertemuan I, II, dan III terlaksana sebesar $100 \%$. Keterlaksanaan tahapan pembelajaran $100 \%$ juga menyisakan beberapa kendala dalam pembelajaran, diantaranya: pada pertemuan I, waktu untuk satu pertemuan menjadi bertambah dari waktu yang direncanakan. Penambahan waktu pertemuan disebabkan karena terdapat tahapan pembelajaran yang masih belum dipahami oleh siswa dengan baik. Tahapan tersebut adalah merumuskan permasalahan dan hipotesis. Hal ini dikarenakan siswa belum terbiasa dengan tahapan tersebut. Pada pertemuan III juga terjadi penambahan waktu pembelajaran, dikarenakan siswa belum memahami cara penggunaan dan pembacaan hasil pengukuran dengan menggunakan alat ukur panjang jangka sorong.

Kendala dalam kegiatan pembelajaran pada pertemuan I, dan III diatasi dengan cara: guru membantu siswa dalam merumuskan hipotesis dan cara penggunaan serta pembacaan hasil pengukuran dari alat ukur jangka sorong berupa pemberian bimbingan kepada siswa yang mengalami kesulitan. Pemberian bimbingan dilakukan untuk efisiensi waktu dan mengurangi aktivitas siswa yang tidak relevan selama kegiatan praktikum berlangsung. Aktivitas siswa yang tidak relevan seperti siswa bercerita dapat menggangu kelancaran kegiatan praktikum karena peneliti harus membimbing tiap-tiap kelompok untuk diberikan penjelasan secara bergantian. Waas dalam Rasmawan (2013) berpendapat bahwa siswa cenderung melakukan kegiatan di luar pembelajaran, jika guru tidak segera memberikan scaffolding kepada siswa.

Dari setiap kegiatan praktikum yang dilakukan siswa, diamati dan dicatat sebagai hasil pengamatan. Hasil pengamatan siswa selama melakukan percobaan selanjutnya didiskusikan dalam kelompok. Selain diskusi tentang hasil pengamatan, setiap kelompok juga mendiskusikan prosedur matematis yang terdapat dalam buku siswa. Anggota kelompok yang memiliki kemampuan heterogen memungkinkan setiap anggota kelompok dapat membantu anggota kelompok lain yang masih mengalami kesulitan dalam memahami prosedur matematis.

Diskusi dalam kelompok dengan kemampuan yang heterogen sejalan dengan metode pembelajaran kooperatif atau cooperative learning yang mengacu pada metode pengajaran dimana siswa bekerja bersama dalam kelompok kecil dengan kemampuan yang berbeda-beda untuk saling membantu dalam belajar (Slavin dalam Nur, dan Wikandari, 2008). Hasil diskusi kelompok selanjutkan dikomunikasikan secara klasikal. Setiap kelompok secara bergiliran menyampaikan hasil diskusinya lalu mendapatkan tanggapan dari kelompok lain. Selama proses diskusi kelas, peran guru sebagai fasilitator sangat penting agar diskusi kelas tidak membahas tentang hal-hal yang tidak berkaitan dengan tujuan pembelajaran. Peran guru sebagai fasilitator juga sangat diharapkan untuk memberikan kesempatan yang sama kepada semua siswa dalam menyampaikan pendapatnya.

Guru meminta kepada masing-masing kelompok untuk membagi bahan hasil diskusinya kepada masingmasing anggota kelompok agar setiap anggota kelompok mendapatkan kesempatan yang sama untuk tampil di depan kelas. Arends (2008) berpendapat bahwa guru sebagai fasilitator dalam pembelajaran diharapkan dapat mengarahkan siswa agar lebih aktif dalm pembelajaran.

Kegiatan penutup pada pertemuan pertama, guru menguji pemahaman siswa tentang seberapa dalam konsep kalor telah dipahami setelah siswa melakukan kegiatan praktikum dan diskusi. Guru bertanya kepada siswa: "Setelah anda melakukan praktikum kegiatan 1, apa itu kalor?", Jawaban siswa beragam dan sebagian besar siswa menjawab: "energi panas pak", lalu peneliti balik bertanya kepada salah satu siswa yang menjawab energi panas tadi: "bisakah anda memberikan contohnya?" lalu siswa tersebut menjawab: "tadi pak, ketika memanaskan air, panasnya pindah dari api ke air dalam gelas ukur". Lalu peneliti memperagakan demonstrasi kepada siswa: "perhatikan kedua telapak tangan saya, keduanya memiliki suhu yang sama. Sekarang saya gosokkan kedua telapak tangan saya ini dalam arah yang berlawanan". Beberapa saat kemudian peneliti mengatakan: "kok kedua telapak tangan saya menjadi hangat? Dari mana hangatnya ini?".

Peneliti tidak melanjutkan dan meminta siswa untuk memahami contoh soal yang diberikan dalam buku siswa dan mengerjakan latihan soal sebagai tugas di rumah. Salah satu tugas guru yang paling penting adalah menjadikan informasi bermakna bagi siswa dengan cara mempresentasikan informasi itu secara 
jelas dan terorganisasi dengan baik, dengan cara menghubungkan informasi itu dengan informasi yang telah ada dalam benak siswa, dan dengan meyakinkan bahwa setiap siswa telah benar-benar memahami konsep yang telah diajarkan (Nur, dkk, 2008).

Tahapan pembelajaran yang menjadi kendala selama pertemuan I telah dapat teratasi pada pertemuan kedua, dimana siswa sudah dapat merumuskan masalah dan hipotesis dengan baik. Kendala pada pertemuan III, dimana terdapat sebagian siswa yang belum memahami penggunaan dan pembacaan hasil pengukuran dari alat ukur jangka sorong. Siswa yang belum memahami penggunaan dan pembacaan hasil pengukuran alat ukur jangka sorong dibantu oleh guru dan siswa dalam kelompok yang telah memahami penggunaan dan pembacaan hasil dari alat ukur tersebut, sehingga siswa dapat melakukan praktik dengan baik sesuai dengan prosedur. Secara umum, implementasi perangkat pembelajaran dapat terlaksana dengan baik.

\section{Aktivitas Siswa dalam Proses Pembelajaran}

Aktivitas siswa yang terjadi di dalam proses pembelajaran diamati oleh dua orang pengamat, yaitu guru mata pelajaran Fisika dan Matematika. Peneliti memilih satu orang pengamat dari guru mata pelajaran Matematika, karena jumlah guru Fisika di sekolah hanya satu orang. Pertimbangan lain dalam pemilihan pengamat dari guru Matematika, karena perangkat pembelajaran yang dikembangkan oleh peneliti diintegrasikan juga dengan prosedur matematis. Kedua pengamat melakukan pengamatan terhadap 9 aktivitas siswa selama mengikuti kegiatan pembelajaran. Pengamatan aktivitas siswa terbagi dua, yaitu: pengamatan aktivitas untuk satu kelompok siswa dan pengamatan aktivitas secara klasikal. Hasil pengamatan aktivitas siswa disajikan sebagai berikut:

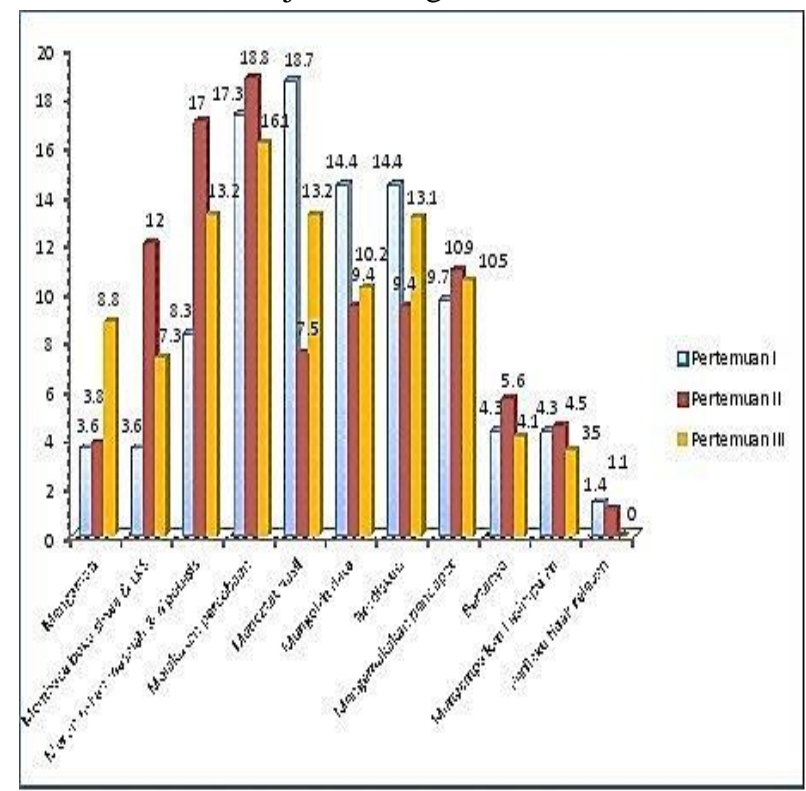

Gambar 4. Aktivitas siswa dalam kegiatan pembelajaran
Pembelajaran Fisika berbasis pendekatan ilmiah yang diintegrasikan dengan prosedur matematis menempatkan guru sebagai fasilitator dalam pembelajaran. Hal ini tergambar pada aktivitas siswa dalam mengikuti proses pembelajaran, dimana aktivitas yang dominan adalah merumuskan masalah dan hipotesis $(15,93 \%)$ dan melakukan percobaan $(17,40 \%)$. Aktivitas siswa yang berhubungan dengan proses pembelajaran secara langsung meningkatkan kualitas belajar siswa menjadi deep learning (Light, dkk, 2009). Aktivitas yang tidak dominan diantaranya: bertanya (4,67\%), menyampaikan kesimpulan $(4,10 \%)$, dan perilaku tidak relevan $(2,5 \%)$.

Aktivitas yang berkaitan dengan perilaku yang tidak relevan selama pembelajaran berlangsung, yaitu siswa diam, bingung, dan bercerita dengan persentasi rata-rata $2,5 \%$. Perilaku yang tidak relevan selama pembelajaran sebanding dengan aktivitas bertanya siswa yang kurang $(4,67 \%)$.

Guru sebagai fasilitator dalam pembelajaran dapat membantu siswa yang diam dan bingung dengan memberikan pertanyaan awal kepada siswa tersebut. Jacobsen, dkk (2009) berpendapat bahwa: guru harus mempertimbangkan tujuan atau alasan mengajukan pertanyaan-pertanyaan tertentu.

Pertanyaan awal dari guru kepada siswa yang diam dan bingung dapat menarik minat siswa untuk bertanya balik kepada guru tentang permasalahan yang dihadapi siswa. Bimbingan guru kepada siswa yang mengalami kesulitan dalam melakukan tahapan pembelajaran juga dapat mengurangi aktivitas siswa yang tidak relevan sehingga setiap tahapan pembelajaran dapat dilakukan oleh siswa dengan baik.

\section{Hasil Belajar Siswa}

Hasil belajar siswa yang dinilai dari penelitian ini mencakup tiga kompetensi, yaitu kompetensi pengetahuan, keterampilan, dan sikap.

1. Hasil belajar kompetensi pengetahuan

Penilaian hasil belajar kompetensi pengetahuan berupa pemberian test kepada siswa dalam bentuk soal uraian. Penilaian hasil belajar kompetensi pengetahuan lebih menekankan pada penguasaan konsep kalor dan kemampuan matematis siswa. Tes hasil belajar kompetensi pengetahuan diberikan sebelum siswa mengikuti pembelajaran berbasis pendekatan ilmiah yang diintegrasikan dengan prosedur matematis (pretest) dan sesudah diberi pembelajaran berbasis pendekatan ilmiah yang diintegrasikan dengan prosedur matematis (posttest). Dari hasil pretest dan posttest, kemudian dicari gain score untuk masing-masing siswa. Gain score siswa untuk kategori tinggi sebesar 25\%, kategori sedang sebesar $75 \%$, dan kategori rendah sebesar $0 \%$. 
Permendikbud Nomor 66 Tahun 2013 menjelaskan bahwa Penilaian terhadap pengetahuan peserta didik dapat dilakukan melalui tes tulis, tes lisan, dan penugasan. Sejalan dengan Permendikbud di atas, peneltian ini menggunakan tes tertulis sebagai penilaian terhadap pengetahuan peserta didik.

Hasil pretest dalam penelitian ini menunjukkan bahwa $100 \%$ siswa tidak tuntas secara individu maupun klasikal, sedangkan hasil posttest menunjukkan peningkatan dimana $75 \%$ siswa tuntas secara klasikal (lampiran 11). Standar penilaian yang tertuang dalam salinan Permendikbud Nomor 66 Tahun 2013 menyatakan bahwa persentase ketuntasan minimal secara klasikal untuk setiap mata pelajaran adalah $75 \%$. Hasil posttest dalam penelitian ini menunjukkan bahwa hasil belajar siswa untuk kompetensi pengetahuan telah memenuhi standar ketuntasan minimal kompetensi yang dicapai siswa setelah mengikuti pembelajaran Fisika berbasis pendekatan ilmiah yang diintegrasikan dengan prosedur matematis.

\section{Hasil belajar kompetensi sikap}

Kurikulum 2013 membagi kompetensi sikap menjadi dua, yaitu sikap spiritual yang terkait dengan pembentukan peserta didik yang beriman dan bertakwa, dan sikap sosial yang terkait dengan pembentukan peserta didik yang berakhlak mulia, mandiri, demokratis, dan bertanggung jawab (Permendikbud No.66, 2013). Kedua bagian kompetensi sikap siswa di atas menjadi dasar dalam penelitian ini dengan indikator yang meliputi: rasa syukur, jujur, tanggung jawab, dan disiplin.

Hasil pengamatan guru menyimpulkan bahwa hampir semua indikator sikap siswa muncul pada saat mengikuti pembelajaran berbasis pendekatan ilmiah yang diintegrasikan dengan prosedur matematis. Persentase ketuntasan kompetensi sikap siswa dalam pembelajaran sebesar $95 \%$ pada pertemuan I, dan $100 \%$ pada pertemuan II, dan III secara klasikal maupun individu. Dengan kata lain, setiap indikator sikap siswa muncul dalam pembelajaran, baik sikap spiritual maunpun sosial.

\section{Hasil belajar kompetensi keterampilan}

Cakupan penilaian kompetensi keterampilan meliputi keterampilan peserta didik yang dipelajari di sekolah dan sumber lain yang sama dalam sudut pandang/teori. Keterampilan ini meliputi: keterampilan mencoba, mengolah, menyaji, dan menalar (Permendikbud No.66, 2013). Indikator penilaian untuk dimensi keterampilan pada penelitian ini meliputi: 1) hasil pengamatan; 2) melakukan praktik; dan 3) mempresentasikan hasil praktik. Dari hasil pengamatan guru terhadap aspek keterampilan ini, diperoleh persentase ketuntasan sebesar $100 \%$ pada pertemuan I, 95\% pada pertemuan II, dan $100 \%$ pada pertemuan III untuk ketuntasan secara klasikal dan individual. Dengan kata lain, siswa memperoleh hasil pengamatan dalam setiap kegiatan praktikum secara lengkap, melakukan praktik sesuai dengan prosedur, dan mampu mempresentasikan hasil praktik dengan benar, bahasa yang mudah, serta disampaikan dengan penuh percaya diri. Ketercapaian ketuntasan dimensi keterampilan ini memberikan pengalaman belajar kepada siswa untuk terlibat secara aktif dalam kegiatan pembelajaran dan mengembangkan kemampuan berfikir sistematis siswa.

\section{E. Respon Siswa Setelah Pembelajaran}

Respon siswa diperoleh dari angket respon yang diberikan kepada siswa setelah diberikan pembelajaran Fisika berbasis pendekatan ilmiah yang diintegrasikan dengan prosedur matematis pada materi kalor. Pertanyaan dalam angket siswa dibagi ke dalam 6 bagian yang meliputi: daya tarik, keterbaruan, kemudahan, minat, bimbingan guru, dan tanggapan terhadap pembelajaran Fisika berbasis pendekatan ilmiah yang diintegrasikan dengan prosedur matematis.

Tabel 3. Respon Siswa Terhadap Pembelajaran

\section{RESPON SSTII TERHADAP PEIBELLAJARAN}

\begin{tabular}{|c|c|c|c|}
\hline \multirow{2}{*}{$\mathrm{N}_{\mathrm{O}}}$, & \multirow[t]{2}{*}{ Item Respon Sisma } & \multicolumn{2}{|c|}{ Penilaian $(0 \%)$} \\
\hline & & Senang & Tidak senang \\
\hline 1. & $\begin{array}{l}\text { Bagaimzan pendapat anda dengan kegiatzan pembelajzan yang } \\
\text { telah anda iwat? }\end{array}$ & 100 & 0 \\
\hline \multirow[t]{7}{*}{2.} & Bagaimana pendzpet anda terhadzp komponen berlust in: & & \\
\hline & a. Mateai isi pelajaran & 65 & 35 \\
\hline & b. Bubusisma & 95 & 5 \\
\hline & c. Prosedur matematis dalam bulks siswa & 75 & 25 \\
\hline & d. Lembar hegiatan sisma (LKS) & 75 & 25 \\
\hline & e. Suasana belajaz di kelas & 80 & 20 \\
\hline & f. Caraguru mengajar & 100 & 0 \\
\hline \multirow[t]{7}{*}{3.} & $\begin{array}{l}\text { Apalah anda meras baru tehadap komponent tomponen } \\
\text { betilot: }\end{array}$ & Baru & Tidak baru \\
\hline & a. Materi isi pelajazan & 55 & 45 \\
\hline & 6. Bukv siswa & 85 & 15 \\
\hline & c. Prosecor matematis dalam bukv siswa & 85 & 15 \\
\hline & d. Lembar kegiatansiswa(LKS) & 75 & 25 \\
\hline & e. Svasana be ajar di kelas & 50 & 50 \\
\hline & f. Cara gurs mengajar & 70 & 30 \\
\hline \multirow[t]{9}{*}{4.} & 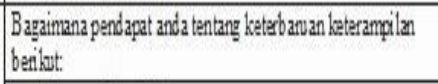 & Baru & Tidak baru \\
\hline & 2 Mengyunakan alat & 45 & 55 \\
\hline & b. Mengindentifikas masalah & 55 & 45 \\
\hline & c. Menumushan pertanyazn & 55 & 45 \\
\hline & d. Membuat jary aban sementza hipocesis & 90 & 10 \\
\hline & e. Melalwilan percobaan & 35 & 65 \\
\hline & f. Menuliskan hassil percobazan & 30 & 70 \\
\hline & g. Menjarzab pertzyyazn petanyazn diskusi & 15 & 85 \\
\hline & h. Menympultan hasil pengamatan & 30 & 70 \\
\hline
\end{tabular}




\begin{tabular}{|c|c|c|c|}
\hline \multirow[t]{7}{*}{5.} & 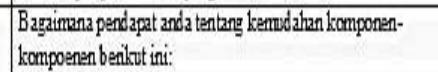 & Mudah & Tidakmudah \\
\hline & a. Materiisi pelajaran & 55 & 45 \\
\hline & b. Buku siswa & 75 & 25 \\
\hline & c. Prosedur matematis dalambuluv siswa & 65 & 35 \\
\hline & d. Lembarkesiatan siswa (LKS) & 65 & 35 \\
\hline & 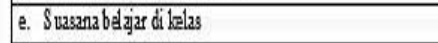 & 90 & 10 \\
\hline & f. Can guru mengajus & 90 & 10 \\
\hline \multirow[t]{9}{*}{6.} & $\begin{array}{l}\text { Bagaimana pend zpat anda tentang kenwd ahan keterampilan } \\
\text { beilut: }\end{array}$ & Mudah & Tidaknudah \\
\hline & 2. Menggunalan alat & 90 & 10 \\
\hline & b. Mengindentifikasi massalah & 50 & 50 \\
\hline & c. Merumushan pestanyazn & 60 & 40 \\
\hline & d. Membuat jarwaban sementara hipotessis & 70 & 30 \\
\hline & e. Melalulan percobazan & 90 & 10 \\
\hline & f. Menvilistan hasil percobaan & 85 & 15 \\
\hline & 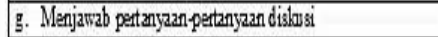 & 65 & 35 \\
\hline & h. Menyimpullenn hasil pengamatan & 65 & 35 \\
\hline \multirow[t]{10}{*}{7.} & 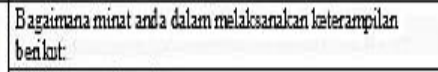 & Senang & Tidak senang \\
\hline & 2. Mengyonalan alat & 100 & 0 \\
\hline & b. Mengindentifilasi massalah & 75 & 25 \\
\hline & c. Merrumushan pertanyzazn & 70 & 30 \\
\hline & d. Membuat jara bans sementara hipoteis & 80 & 20 \\
\hline & e. Melalavian percobazan & 100 & 0 \\
\hline & f. Menuliskan hasil percobazan & 85 & 15 \\
\hline & g. Menjarazb pestanyazn petanyazn dislowi & 85 & 15 \\
\hline & h. Menyimpullan hasil pengamatan & 80 & 20 \\
\hline & & Baik & Tidak baik \\
\hline 8. & $\begin{array}{l}\text { Bagaimana bimbing an guru pada sat penbelajazan } \\
\text { betangsong? }\end{array}$ & 100 & 0 \\
\hline \multirow[t]{2}{*}{9.} & $\begin{array}{l}\text { Bagaimzna bimbingan guru pada saza anda neryylesailan } \\
\text { LKS? }\end{array}$ & 85 & 15 \\
\hline & & Setuju & Tidak setuju \\
\hline 10. & 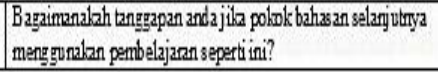 & 100 & 0 \\
\hline
\end{tabular}

Respon siswa terhadap pembelajaran adalah $100 \%$ siswa senang terhadap pembelajaran Fisika berbasis pendekatan ilmiah yang diintegrasikan dengan prosedur matematis, siswa senang terhadap komponenkomponen pembelajaran, yaitu materi/isi, buku siswa, prosedur matematis, LKS, suasana belajar, dan cara guru mengajar. Jadi, komponen pembelajaran Fisika berbasis pendekatan ilmiah yang diintegrasikan dengan prosedur matematis dapat membantu siswa untuk belajar dalam suasana yang menyenangkan.

Respon siswa terhadap keterbaruan komponenkomponen pembelajaran adalah siswa merasa baru terhadap buku siswa (85\%), prosedur matematis (85\%), LKS $(75 \%)$, dan cara guru mengajar (70\%). Respon siswa terhadap keterbaruan keterampilan dalam pembelajaran adalah siswa merasa baru untuk keterampilan mengidentifikasi masalah (55\%), merumuskan pertanyaan (55\%), dan membuat jawaban sementara/hipotesis (90\%), Jadi, siswa merasa ada variasi dalam pembelajaran dan tidak terkesan monoton dengan metode pembelajaran yang sama dalam pembelajaran Fisika.

Respon siswa terhadap kemudahan dalam memahami komponen-komponen pembelajaran adalah siswa merasa mudah dalam suasana belajar di kelas
(90\%), dan cara guru mengajar (90\%). Respon siswa terhadap kemudahan dalam keterampilan adalah siswa merasa mudah dalam menggunakan alat (90\%), melakukan percobaan (90\%), menuliskan hasil percobaan (85\%). Hasil respon ini menunjukkan bahwa siswa dapat belajar secara mandiri dalam memahami materi kalor dengan baik.

Respon siswa terhadap minat dalam melaksanakan keterampilan adalah siswa sangat senang terhadap keterampilan menggunakan alat (100\%), dan melakukan percobaan (100\%). Ketika siswa sangat tertarik dan tertantang terhadap permasalahan dalam pembelajaran, maka siswa akan sangat antusias dalam mengikuti proses pembelajaran untuk menemukan sendiri jawaban atas permasalahannya. Menurut Arends (2008), jika masalah yang diberikan kepada siswa membuat siswa merasa tertantang, baru, dan menarik maka dalam proses pembelajarannya siswa akan mengerahkan seluruh upaya untuk menyelesaikan masalah yang diberikan kepada siswa dan dapat memicu motivasi intrinsik di dalam diri siswa.

Respon siswa terhadap bimbingan guru adalah siswa merasa guru baik dalam membimbing selama pembelajaran (100\%) dan bimbingan pada saat menyelesaikan LKS (85\%). Dengan demikian siswa merasa terbantu dalam memahami setiap proses pembelajaran dan dapat menjawab pertanyaanpertanyaan pada LKS untuk meningkatkan pemahaman konsep siswa tentang kalor.

Respon siswa terhadap pembelajaran Fisika berbasis pendekatan ilmiah yang diintegrasikan dengan prosedur matematis adalah $100 \%$ siswa sangat berminat jika pembelajaran berbasis pendekatan ilmiah diajarkan untuk pokok bahasan selanjutnya.

\section{F. Temuan Dalam Penelitian}

Temuan dari hasil uji pengembangan kuantitatif perangkat pembelajaran Fisika berbasis pendekatan ilmiah yang diintegrasikan dengan prosedur matematis pada materi kalor dapat diuraikan sebagai berikut:

1. Hasil penilaian validator terhadap Rencana Pelaksanaan Pembelajaran (RPP) sebesar 3,5 dengan kategori layak digunakan, buku siswa sebesar 3,8 dengan kategori layak digunakan, Lembar Kerja Siswa (LKS) sebesar 4,29 dengan ketegori layak digunakan, tes hasil belajar kompetensi pengetahuan setiap soal berada pada kategori valid dan mudah dipahami, tes hasil belajar kompetensi keterampilan berada pada kategori valid dan mudah dipahami, dan tes hasil belajar kompetensi sikap berada pada kategori valid dan mudah dipahami.

2. Keterlaksanaan rencana pelaksanaan pembelajaran pada pertemuan I, II, dan III dapat terlaksana $100 \%$.

3. Pada setiap pertemuan, aktivitas siswa secara dominan menunjukkan aktivitas yang berhubungan 
dengan proses pembelajaran antara lain mengamati, membaca buku siswa dan LKS, merumuskan masalah dan hipotesis, melakukan percobaan, mencatat hasil pengamatan, mengolah data hasil pengamatan, berdiskusi dalam kelompok, mengemukakan pendapat, bertanya, dan menyampaikan kesimpulan.

4. Siswa memberikan respon positif terhadap komponen, keterbaruan, kemudahan, minat, bimbingan guru, dan harapan siswa agar pembelajaran Fisika berbasis pendekatan ilmiah yang diintegrasikan dengan prosedur matematis dapat di terapkan pada pokok bahasan selanjutnya.

5. Hasil belajar kompetensi pengetahuan siswa mengalami peningkatan dengan gain score kategori tinggi sebesar $25 \%$, kategori sedang sebesar $75 \%$, dan kategori rendah sebesar $0 \%$ setelah diberikan pembelajaran Fisika berbasis pendekatan ilmiah yang diintegrasikan dengan prosedur matematis. Ketuntasan hasil belajar kompetensi pengetahuan siswa (posttest) sebesar $75 \%$ secara klasikal, ketuntasan hasil belajar kompetensi keterampilan sebesar 98,3\% secara klasikal, dan ketuntasan hasil belajar kompetensi sikap sebesar $98,3 \%$ secara klasikal.

Kendala yang menghambat kegiatan pembelajaran pada pertemuan I adalah siswa masih kesulitan dalam merumuskan masalah dan hipotesis, dan kurangnya pemahaman penggunaan dan pembacaan hasil pengukuran dari alat ukur jangka sorong menjadi kendala pada pertemuan III.

\section{KESIMPULAN}

\section{A. Simpulan}

Berdasarkan hasil temuan yang diperoleh peneliti, maka dapat disimpulkan bahwa perangkat pembelajaran Fisika berbasis pendekatan ilmiah yang diintegrasikan dengan prosedur matematis efektif untuk meningkatkan hasil belajar siswa pada materi kalor tingkat SMA.

\section{B. Saran}

Saranyang diberikan dari hasil temuan dalam penelitian ini adalah:

1. Diperlukannya pertemuan tambahan di awal untuk melatih siswa dalam merumuskan masalah, hipotesis, dan prosedur penggunaan serta pembacaan hasil pengukuran dari alat ukur yang digunakan dalam kegiatan praktikum.

2. Perlu dilakukan penelitian lanjutan yang mengintegrasikan prosedur matematis dalam pembelajaran Fisika dengan model pembelajaran dan pokok bahasan lain untuk meningkatkan hasil belajar siswa.

\section{REFERENSI}

Arends, R.I. (2008). Learning to Teach. Yogyakarta: Pustaka Pelajar.

Borich, G.D. (1994). Observation Skill For Effective Teaching. New York: Mac Millan Publishing Company.

Checkland, P. (1993). Systems Thinking, Systems Practice. New York: John Wiley and Sons, LTD

Gedgrave, I. (2009). Modern Teaching of Physics. New Delhi: Global Media.

Hake, R.R. (1999). "Analyzing Change/Gain Score".. Indiana University (Mailing list posting of $22 \mathrm{Feb}$ 1999): Dept. of Physics.

Jacobsen, D.A., Eggen, P. and Kauchak, D. (2009). Methods for Teaching. Jakarta: Pustaka Pelajar.

Kemendikbud. (2013a). Permendikbud Nomor $81 a$ Tentang Implementasi Kurikulum. Jakarta.

Kemendikbud. (2013b). Permendikbud Nomor 66 Tentang Standar Penilaian. Jakarta.

Kereh, C.T., Sabandar, J. dan Tjiang, P.C. (2013). "Identifikasi Kesulitan Belajar Mahasiswa Dalam Konten Matematika Pada Materi Pendahuluan Fisika Inti". Prosiding Seminar Nasional Sains dan Pendidikan Sains VIII, Fakultas Sains dan Matematika. UKSW. Vol 4, No 1, ISSN:20870922.

Kilpatrick, J., Swafford, J. and Findell, B. (2001). Adding It Up: Helping Children Learn Mathematics. Reston: NCTM.

Kurniasih, I. dan Sani, B. (2014). Implementasi Kurikulum 2013; Konsep dan Penerapan. Jakarta: Kata Penal.

Lazim, M. (2013). Penerapan Pendekatan Saintifik Dalam Pembelajaran Kurikulum 2013. Artikel. Yogyakarta.

Mirawati, L., Asim. dan Masjkur, K. (2013). Diagnosis Kesulitan Belajar Fisika Pokok Bahasan Kalor Siswa Kelas X-D Madrasah Aliyah Negeri 3 Malang. Universitas Negeri Malang.

Nur, M. dan Wikandari, P.R. (2008). Pengajaran Berpusat Kepada Siswa dan Pendekatan Konstruktivis Dalam Pengajaran. Surabaya: Pusat Sains dan Matematika Sekolah, Universitas Negeri Surabaya.

Nur, M., Wikandari, P.R. dan Sugiarto, B. (2008). Teori Pembelajaran Kognitif. Surabaya: Pusat Sains dan Matematika Sekolah. Universitas Negeri Surabaya.

Prabowo. (2011). Metodologi Penelitian (Sains dan Pendidikan Sains). Surabaya: Universitas Negeri Surabaya.

Putra, A. (2013). "Penerapan Pembelajaran Fisika SMA Berbasis Kegiatan Laboratorium". Prosiding Semirata FMIPA Universitas Lampung. pp. 227-234. 
Rasmawan, R. (2013). Memberdayakan Keterampilan Berpikir Kritis Siswa SMA Melalui Model Pembelajaran Berbasis Inkuiri Pada Materi Laju Reaksi (Tesis magister pendidikan tidak dipublikasikan). Universitas Negeri Surabaya.

Rusli, M.A. (2012). Pembelajaran Fisika Melalui Pendekatan Pemrosesan Top Down Berbasis
Scaffolding Untuk Melatihkan Keterampilan Berpikir Kritis (Tesis magister pendidikan tidak dipublikasikan). Universitas Negeri Surabaya.

Walle, J.A.V.D. (2008). Pengembangan Pengajaran Matematika Sekolah Dasar dan Menengah. Jakarta: Erlangga. 